\title{
A FEDERAÇÃO BRASILEIRA DOS CENTROS DE ESTUDOS HISTORICOS E O III SEMINÁRIO INTERUNIVERSITÁRIO DE ESTUDANTES DE HISTORIA.
}

\author{
HERÓDOTO BARBEIRO \\ Presidente do Centro de Estudos Históricos "Affonso \\ d'Escragnolle Taunay", dos alunos da Faculdade de Fi- \\ losofia, Ciências e Letras da Universidade São Paulo.
}

Belo Horizonte foi sede, de 29 de abril a 4 de maio de 1967, do III Seminário Interuniversitário de Estudantes de História, promovido pelo Centro de Estudos Históricos da Universidade Federal de Minas Gerais, tendo comparecido 20 delegações; de São Paulo (Universidades de São Paulo, Católica, de Campinas, Faculdade de Filosofia de Lins, de Santos, de Assis, de Bauru e de Lorena), Minas Gerais (Universidades Federal e Católica de Belo Horizonte, Faculdades de Uberlândia, Uberaba, Montes Claros, Itaúna), Rio Grande do Sul (Pôrto Alegre), Paraná (Faculdades de Curitiba e Ponta Grossa), Goiás (Goiânia) e Rio de Janeiro (Niterói). Os Seminários Interuniversitários de Estudantes de História passaram a ser realizados quando a Federação Brasileira dos Centros de Estudos Históricos deixou de existir. Sua primeira sede foi a cidade de Franca, a segunda Lins e a terceira Belo Horizonte.

O tema do III Seminário foi $O$ Ciclo do Ouro na Evolução Histórica do Brasil, sendo que, paralelamente, desenvolver-se-ia a restruturação da Federação e para tanto os Centros de Estudos Históricos receberam com antecedência os estatutos da antiga Federação para o preparo de sugestões a serem postas em discussão, com os demais colegas de outros Estados, assim como o preparo de trabalhos e teses atinentes ao Ciclo do Ouro.

29 de abril.

17 horas: Abertura do III Seminário pela presidente do Centro de Estudos Históricos da Universidade Federal de Minas Gerais, dando as boas-vindas aos seminaristas. Em seguida realizou-se a conferência do Professor João Camilo de Almeida Tôrres, tratando do tema $O$ Ciclo do Ouro na História de Minas Gerais. 
18 horas: Coquetel na sede social do D.C.E., seguindo-se visitas aos pontos de diversões da cidade.

\section{0 de abril.}

8,30 horas: Sessão plenária, com a apresentação das delegações e eleição da mesa diretora dos trabalhos, que ficou assim constituída: Heródoto Barbeiro, do Centro de Estudos Históricos "Afonso d'E. Taunay", presidente e Inês Etienne, do Centro de Estudos Históricos da Universidade Federal de Minas Gerais, vice-presidente.

11 horas: Início dos debates referentes à Federação.

14 horas: Visita aos pontos turísticos da cidade, assim como ao Museu Colonial, a Pampulha e o Estádio de Futebol (o Mineirão).

\section{$10^{\circ}$ de maio.}

8,30 horas: Reunião no prédio da Faculdade de Filosofia, com o prosseguimento dos debates em tôrno do tema Federação.

11 horas: Sessão plenária com debates relativos às finalidades da Federação, assim como sôbre o relatório apresentado sôbre $\mathrm{OCi}$ clo do Ouro pelos colegas da Universidade Católica de São Paulo, com distribuição das teses mimeografadas e exemplares da Revista de História pela delegação da Universidade de São Paulo.

14 horas: Conferência na sede do D.C.E. pelo professor Fernando Correia Dias, que discorreu sôbre o tema: Região Mineradora e o Caráter Regional de Minas Gerais.

15,30 horas: Debates em tôrno do tema acima, com relatório de grupos compostos de elementos de diversas delegações.

20 horas: Sessão plenária, tratando de aspectos do problema da História no ambiente nacional, com debates e esclarecimentos por parte dos membros das diferentes delegações participantes.

\section{2 de maio.}

8,30 horas: Visita à cidade de Ouro Prêto, em ônibus especial, destacando-se pontos como o Museu, Faculdade de Minas e Metalurgia, casa de Gonzaga, diversas igrejas e pontos turísticos. A visita prolongou-se por todo o dia, e pôde-se ter uma idéia do que realmente foi a cidade de Ouro Prêto no seu período áureo.

\section{3 de maio.}

8,30 horas: Conferência do professor Francisco Iglésias sôbre a Fisionomia do Ciclo do Ouro. 
10. horas: Debates sôbre o tema discorrido e a posterior apresentação dos relatórios dos grupos.

16 horas: Sessão plenária, tendo sido iniciada a modificação dos Estatutos da nova Federação, uma vez que a idéia de uma Executiva Nacional, não foi aceita pelo plenário.

20 horas: Continuação da sessão plenária, sendo discutido e aprovado item por item do nôvo estatuto da Federação, tendo prèviamente se estabelecido que os votos seriam dados por bancadas.

\section{4 de maio.}

8,30 horas: Conferência no D.C.E. do professor Sílvio de Vasconcelos, que falou sôbre $A$ Arte Barrôca Mineira.

10 horas: Segundo o que rezava o Regulamento do III Seminário, foi feita a leitura dos novos Estatutos aprovados na sessão anterior, e a escôlha da sede para o próximo seminário, que já será feito sob a égide da Federação. Duas cidades se apresentaram: Pôrto Alegre e Curitiba. Submetidas à votação do plenário, Pôrto Alegre foi escolhida como futura sede e Curitiba ficou como suplente. Depois disso foram abertas inscrições de chapas para a primeira diretoria, apresentando-se uma formada de elementos de São Paulo e outra de colegas de Minas Gerais. Submetidas ao voto das delegações foi eleita a chapa composta de Heródoto Barbeiro, presidente (Universidade de São Paulo), Maria Lúcia Leonardi, vice-presidente (da Pontifícia Universidade Católica de São Paulo), José Roberto dos Santos, secretário (da Pontifícia Universidade Católica de São Paulo )e Osvaldo Souza Aranha, tesoureiro (Universidade de São Paulo) .

14 horas: Em ônibus especial foi feita uma excursão a Sabará, sendo visitada a Igreja de Nossa Senhora do O', Matriz de Nossa Senhora da Conceição, Igreja de Nossa Senhora do Rosário dos Pretos, Chafariz do Caquende e o Museu do Ouro. Esta visita foi tôda acompanhada por um guia especializado que forneceu informações sôbre os locais visitados.

19 horas: Posse da primeira diretoria dà Federação Brasileira dos Centros de Estudos Históricos, sendo que a mesma foi dada pela Presidente do Centro de Estudos Históricos da Universidade Federal de Minas Gerais. Em nome da nova diretoria falou o presidente eleito.

A realização do III Seminário Interuniversitário dos Estudantes de História, veio demonstrar que no campo do historiador há muito o que se fazer e a prova disso, tivemos no esfôrço dos colegas de Minas Gerais, no sentido do êxito do Seminário que, diga-se de passa- 
gem, foi completo. Deixamos aqui um voto de profundo reconhecimento pelo trabalho insano desenvolvido pelos colegas de Minas Gerais. As perspectivas que se abrem com a fundação da Federação são as mais amplas possíveis e a atual diretoria dispóe-se a tratar dos problemas mais urgentes e que afetam de perto àquêles que freqüentam o curso de História nas diferentes Faculdades de Filosofia do Brasil. Todo um trabalho de base, de estruturação, está ainda por ser feito, desde a parte burocrática até a de maior interêsse, ou seja, a regulamentação da profissão. A Federação Brasileira dos Centros de Estudos Históricos, já conta com um esbôço de anteprojeto, a ser levado à Câmara Federal pelo deputado Evaldo de Almeida Pindo, M.D.B. de São Paulo, onde procura-se regulamentar a atuação daqueles que fazem História, procurando defender os seus direitos.

E' ainda, através dessa mesma Federação, que se pretende difundir os novos conhecimentos que a ciência histórica conquista, e para isso a Federação está subdividida em Seções Estaduais, com um encôntro anual, promovendo reuniões e difundindo temas de interêsse dos que se dedicam ao estudo da História. A falta de uma entidade que congregasse os Centros de Estudos Históricos do Brasil, foi suprida, agora só nos resta promover, através dessa instituição, um interçâmbio que possibilite uma maior consciência dos deveres e direitos que o historiador tem perante a cultura e a sociedade brasileira. 